\title{
Ultramodern Psychology: A Vision Construction with Culture, Religion, Cognitive Science and Neurotheology*
}

\author{
Yusuf Firınc1 ${ }^{1}$
}

\begin{abstract}
This research paper focuses on the evaluation of historical connections and interactions between psychology, psychiatry, psychologists, beliefs and religions. The argument of this research is; for developing future perspectives on psychology, religion can possibly provide historical and modern tools, as well as various other contributions. Within the scope of this research paper, the main idea and some other relevant arguments have been developed by evaluating historical facts and scientific analysis presented under the sub-sections of this essay, namely; psychology, beliefs and interdisciplinary connections, nonmaterial beliefs in cultural psychology, science and religion: a synergetic approach is possible, studying psychology and religion, psychology of religion, psychological benefits of religion, interpreting and utilizing new brain sciences of neurotheology and cognitive science. The conclusion briefly summarizes diverse understandings formed through the evaluation of these sub-sections. This research illustrates the coexistence of religious and scientific knowledge using the emergence of modern psychology. On the other hand, some arguments regarding the commercialization of research targets, the transformation of science into neoliberal market discourses leading to some kind of social Darwinism, or regarding some of the influences of some of the sponsors; some of the leaders; some of the foundations; some of the scientism ideologies; and various global agendas are shared to illustrate the necessity to be cautious.
\end{abstract}

\section{Key Words}

Cultural psychology $\bullet$ transpersonal psychology $\bullet$ psychology of religion $\bullet$ cognitive science of religion $\bullet$ neurotheology

\section{Ultramodern Psikoloji: Kültür, Din, Algısal Bilim ve Nöroteoloji ile bir Tasavvur İnşası \\ Öz}

$\mathrm{Bu}$ araştırma makalesi psikoloji, psikiyatri, psikologlar, inançlar ve dinler arasındaki tarihi bağlantılar ve etkileşimlerin değerlendirilmesine odaklanır. Bu araştırmanın savı: psikolojinin gelecek öngörüleri geliştirilmesi için din, muhtemel tarihi ve modern araçlar sağlayabilecek ve diğer çeşitli katkılar sunabilecektir. Bu araştırma makalesinin kapsamı dâhilinde ana fikir ve diğer ilgili argümanlar, tarihi gerçekler ve bu makalenin alt bölümlerindeki bilimsel çözümlemeler değerlendirilmek suretiyle geliştirilmiştir. Bu alt bölümler: psikoloji, inançlar ve disiplinler arası bağlantılar; kültürel psikolojide maddi-olmayan inanışlar; bilim ve din, sinerji yaklaşımının mümkünlüğü; psikoloji ve din üzerine çalışmak; dinin psikolojisi; dinin psikolojik faydaları; yeni beyin bilimlerinden nöroteoloji ve bilişsel (algısal) bilimi yorumlamak ve faydalanmak. Sonuç bölümü ise yukarıda belirtilen alt bölümlerin değerlendirilmesi yoluyla oluşturulan muhtelif anlayışları kısaca özetler. Bu araştırma, modern psikolojinin ortaya çıkışını kullanarak dini ve bilimsel bilginin bir arada varlığını tasvir eder. Diğer taraftan, araştırma amaçlarının ticarileşmesi, bilimin çeşitli Toplumsal Darwinci türlerine yönlendiren neoliberal piyasa kavramlarına dönüşümü hakkında veya, muhtelif sponsorların, muhtelif liderlerin, bazı vakıfların, bazı bilimcilik ideolojilerinin ve muhtelif küresel gündemlerin tesirleri hakkında bazı iddialar, dikkatli davranılması gereğine işaret edilmek amacıyla paylaşılmıştır.

\section{Anahtar Kelimeler}

Kültürel psikoloji • benötesi psikoloji $・$ din psikolojisi $\bullet$ bilişsel din bilimi $\bullet$ nöroteoloji

\footnotetext{
* A different version of this work was submitted to the Middle East Technical University, Department of Psychology in partial fulfillment of the requirements for the lecture titled: "Psy 553, Historical Overview of Advances in Social Psychology"

1 Correspondence to: Yusuf Firınc1, Doctoral Student, Sociology of Religion, Istitute of Social Sciences, Ankara University, Ankara, Turkey, E-mail: yusuffirinci@ed-alumni.net
}

Citation: Firınc1, Y. (2019). Ultramodern psychology: a vision construction with culture, religion, cognitive science and neurotheology. Spiritual Psychology and Counseling, 4, 275-307. http://dx.doi.org/10.37898/spc.2019.4.3.080 
It may have been the first time that the discipline of psychology was defined as an ultramodern discipline when Gordon W. Allport (1985) from Harvard University described social psychology simultaneously as an ancient, modern, exciting and ultramodern discipline. After more than six decades, this research paper still illustrates the quest for contemporary 'ultramodern psychology' by offering perspectives utilizing recent social and scientific developments in the field of psychology. This quest is necessary because the literature on psychological science has been widening especially in regards to metatheories. The objective of eliminating some of the gaps in favour of advancement can become easier by connecting the dots within sub-disciplines of psychology and supplementary research fields such as beliefs, cultures and religions.

Similar to all behavioral science, psychology, especially social psychology, rests upon broad metatheories regarding the nature of the human as well as the nature of society and that's why integrative theories are not easy to come by (Allport, p. 42). Thus, a contemporary 'ultramodern' conceptualization attempt within this essay will require the integration of various metatheories.

To conceptualize a new 'ultramodern' psychology and to integrate metatheories together, a researcher may utilize the vast inventory of accumulated findings. It can be argued that; just as Jackson (1988, p. 135) argues about social psychology, the contributions of accumulated research in any sub-discipline of psychology will belong to individual, general psychology. Considering this fact, the utilization of evaluations from various sub-fields within psychology may serve the development of a perspective, valid for general psychology.

The argument of this research paper will be built upon evaluating first the findings and suggestions regarding social psychology. After briefly examining the social and cognitional dimensions, cultural social psychology, within the scope of nonmaterial beliefs, will be evaluated. The relationship between psychology and beliefs will be further developed using the explanatory contributions of the science and religion debate. The need for caution in regards to the way some of the neoliberal agendas have infiltrated their way into new brain sciences will briefly be examined. The place of religion on the individual level, as well as scientific inquiries will help us comprehend the possible combination of new perspectives on psychology in constructive ways.

\section{Psychology, Beliefs and Interdisciplinary Connections}

The word 'psychology' first emerged in the 1500s, whereas the first book with the title 'Psychology' was published by a Protestant theologian Rudolp Goglenius in 1590 (Still, 1998, p. 21). It can be argued that at its origin, of modern psychology was connected to theologians. 
It is not a very well known fact but, the efforts of Protestant philosophers of the Reformation in comparatively neglecting the immortal soul and everlasting verities were balanced by a Counter-Reformation led by Jesuit order of Ignatius Loyola, suggesting a disengagement of the self from the world and the revival of the immortal soul with the assistance of mediation (Still, 1998, p. 22). It can be argued that the beliefs regarding immortal soul and eternal truths had already been somehow added to science again within the eurocentric world by Christian Counter-Reformation schools of thought.

A relatively younger sub-discipline Social Psychology, has been explained as "the scientific investigation of how the thoughts, feelings and behaviours of individuals are influenced, by the actual, imagined or implied presence of others" (Allport, as cited in Hogg, 2003). This is the most widely accepted definition apart from a few exceptions. However there have been various different questions and discussions developed to understand and theorize better. Interestingly, it can clearly be seen even in one of the earliest definitions of modern social psychology that the functions of nonmaterial, imagined or implied factors/ determinants are emphasized.

Social Psychology is a sub-discipline of psychology focusing on the processes of the human mind which requires close scientific interactions between related disciplines such as: cognitive psychology, individual psychology, social anthropology, sociology and sociolinguistics (Hogg \& Vaughan, 2005, p. 5). Considering this fact, it can be argued that the determinants or factors such as religion affecting these aforementioned related disciplines such as cognitive psychology are affecting social psychology both directly and indirectly.

After briefly emphasizing the affects of various determinants, and also the factors that affects those determinants on psychology, it is also worth highlighting the fact that social construction affects psychology. One of the pioneers of research focusing on social psychology as a social construction is Kenneth F. Gergen. Social constructionist inquiry focuses on examining the forms, approaches, ways in which reality is constructed within society and according to the reflexive deliberation perspective, people in relationships move toward collective agreements on what is real, rational and right (Gergen, 1997, pp. 120, 122). The role of religion is also apparent in the construction of psychology, or psychology in construction, considering the fact that religion has been and will be relevant to social constructs in various forms and dimensions.

The societal arena can provide an example on how construction affects psychology. We can examine Gergen's argument on social order discourse construction and psychological replacement. He argues that "we can at last put reigns on the vain hope -from the Ten Commandments to charters of Universal Human Rights- that some 
particular arrangements of words will guarantee the replacement of pain and anguish with happiness for all" (Gergen, 1998, p. 153). Interestingly, while Gergen implies that the replacement of the societal discourse, including religious commandments with human rights charters will provide replacement of pain with happiness, he himself illustrates that the religious commandments have negative constructs and rights charters have positive constructs on his personal cognition.

When we explore the roots of modern social psychology, one of the most important developments may be the utilization of cognitive science in psychology research. Cognitive science can be described as the result of the wartime collaborative efforts of psychologists, telecommunication engineers, computer scientists and Henri Tajfel, who contributed the idea of individualization of the social with theories such as the cognitive theory of prejudice (Farr, 1996). The crucial importance of cognitive science in psychology has been increasingly emphasized by various scholars such as Ulric Neisser, the so-called father of cognitive psychology. An example may be the motivated-tactician model. This model proposes that humans think and choose among various cognitive strategies build upon goals, motives and needs that are affected by self-beliefs, beliefs about others, self-concepts and worldview (Franzoi, 2003, p. 150). In the light of these propositions, it can be argued that cognitive science can be used to comprehend how religion may play a crucial role in the individualization of the social constructs and in the development of self-beliefs, self-concepts and worldviews.

Social cognition is defined as the conceptual and empirical approach to comprehend social psychological phenomena by exploring the cognitive structures and processes by which they operate (Sherman, Judd \& Park, as cited in Devine, Hamilton \& Ostrom, 1994). Social cognition is also related to beliefs and religion just as social norm development. A social norm is an expected typical behavior and belief created and imposed by a group and Muzaffer Şerif Başoğlu's norm development research illustrated that we look to others when defining society (Franzoi, 2003, p. 288). An example illustrating social norm development psychology and its relation with religion may be found in prominent psychologist George Herbert Mead's words on his religion. Social Behaviorist Mead suggests that his religion, “.... paved the way for the social progress - political, economic, scientific- of the modern word, the social progress which is so dominantly characteristic of that world" (Mead, 1934, p. 293). This statement can be interpreted as an example of the social cognition construction or psychological conceptualization of a constructed ideology.

On the other hand, G. H. Mead also emphasized the importance of cognitive structures and cognitive processes within social interaction while stipulating that the individual will take society's attitudes in the form of a generalized other as a result 
of the reflexive self inherent in the cognitive processes (Bush \& Simmons, 1981, pp. $140,141)$. This argument may lead us to suggest that analyzing, understanding and training cognitive processes may transform what individuals take from societies for their reflexive selves, including beliefs, worldviews and religions. However, it is not easy to analyze cognition because cognition emanates from the complex interactions of and the individual's navigations through cognitive acts, enmeshed in content, intentions, context, social and cultural surroundings (Hirst \& Manier, 2008, p. 116). Nevertheless, this complexity will probably not diminish the will of researchers in their quest to discover more about psychology, belief and religion.

Similar to the complexity of cognitive science, there is another obstacle of defining the scope and positioning related to intra-psychological and inter-psychological processes in analyzing behavior. Gün Semin have argued that intra-psychological processes (cognitive and affective) must be interfaced with inter-psychological (social behavior) processes by using mediators of cognition and consciousness such as language approaches (Semin, 1997). To summarize, it is important to emphasize that language has crucial effects on communication, cognition and psychology.

Gordon Allport (1966) also classified conceptions of being religious into two areas: extrinsic religious orientation and intrinsic religious orientation. Extrinsic religious orientation is utilitarian, such as granting safety, social standing, or solace, whereas intrinsic religious orientation considers faith as a supreme value in its own right, not limiting religion to single segments of self-interest (Allport, as cited in Batson et al., 1993)

\section{Nonmaterial Beliefs in Cultural Psychology}

Since the beginning of Millennium times, various cultural transformation trends have been affecting societies and individuals. It can be argued that societies, groups or individuals have been experiencing various forms of external factors' impacts on their values, norms and beliefs in various levels and different dimensions. One of the results of increasingly developing interactions between cultures and beliefs of peoples may be defined as culture shifts. Considering millennial culture shift, Helminiak (2010, p. 70) suggests that to stabilize cultural changes, psychology and psychotherapeutic practices and all other sciences and professions have to be mindful and open to religion. Religion may function as one of the useful factors to formulate various cures to various contemporary challenges.

According to the structure of this research paper, a relevant definition of culture can be found in Emeritus Professor Geert Hofstede's research. Hofstede had profound influence on cross-cultural psychology. Culture is defined as "the collective programming of the mind which distinguishes the members of one group from 
another" (Hofstede, as cited in Smith \& Bond, 1998, p. 48). The mind represents the head, heart and hands for thinking, feeling and acting with effects for beliefs, attitudes and abilities (Hofstede, 2001, p.10).

The fundamental assumption of cultural psychology states that; an individual's experience and behavior are rooted in an expression of the divergent cultural traditions and contexts in which this individual is living with(in) (Lehmann-Murithi, 2017). Culture affects psychology via cognition. Ashbrook and Albright (1999, p. 412) argue that "cognition, or consciousness, connects neuronal activity and cultural influences by mapping mental representations resulting from biochemical processes, following patterns partly derived from culture." Considering these facts, it can be argued that cultural patterns affect individual cognitions via biochemical processes and individual's experience and behavior are shaped by these cultural contexts.

Regarding biochemical processes, recent functional magnetic resonance imaging (fMRI) research findings illustrated the neurobiology underlying strategic social choice, by indicating specific increases in the functional interactions between brain regions previously associated with mentalizing about others' beliefs and key nodes of brain's value computation system (Makwana et al., 2015). This research can be an illustration of the balancing calculations in brain for personal gains in consideration of social norms. The effects of religion and in general, culture on individual cognition and mentalizing about beliefs can be traced through researches focusing on brain's value computational system.

Apart from biochemistry and neurobiology, anthropology is another field that illustrates the relationship between culture and religion. Anthropologist Clifford Geertz, who had a significant effect in cultural psychology of religion, argues that "There is no such thing as human nature independent of culture" (Geertz, as cited in Belzen, 2010, p. 27). The studies on anthropology will also illustrate that the human psychology is interconnected with culture. Similarly, psychology lives in the way along the edge of cultural history and according to the cultural advancement, psychology regularly dialogs with the epochs as (Miller, 2012, p. 1): hysteria in the beginning of the $20^{\text {th }}$ century, IQ testing in the 1940 s, groupthink in the $1950 \mathrm{~s}$, stereotyping in the 1960s \& 1970s, depression in the 1980s \& 1990s, and positive psychology in the 2000s. Cultural advancement may lead us to the epochs such as positive psychology approach in the 2000s but post-positivism, by highlighting the roles of beliefs, illustrated different approaches to reach reality. Today, approaches on psychology may be enriched by researches and methodologies utilizing culture and belief factors.

Furthermore, consciousness of self is socially constructed, psychological reality is in a continuing dialectical connection with communal structure and psychological 
understanding is for all time an element of a broad knowledge concerning the world (Berger, 2013, pp. 116, 122). The psychologically learning process of socialization is conditional on the creation of symmetry among the objective world of society and the subjective world of the self (Berger, 1990, p. 15). The formation, development and evolution of subjective world and psychology are related with and connected to what the individuals' get from their 'outside world'.

It should also be noted that there may be different approaches of different study fields. One of the core premises of cognitive psychology is arguing that there is a central processor common to all humans, but cultural psychology rejects this assumption and focuses on cultural specificity as its starting point (Walkerdine \& Blackman, $2008 \mathrm{p}$. 68). Presumably the central processors of individuals may differentiate according to affecting inputs such as culture and beliefs.

Regarding the beliefs in culture and their effects on individual cognition, it can be argued that cultures differ in the attributions they generate and one aspect of culture, beliefs are extremely significant since the process we comprehend (interpret) a behavior is determined by the attributions we use (Triandis, 1994, p. 96). According to attribution theory, humans try to find out why individuals do what they do in order to discover the feelings and traits that are behind their actions (Aronson, Wilson \& Akert, 2005, p. 128). Considering these information, one can argue that beliefs are crucial in cognition and psychology since beliefs and religions may affect feelings and traits that cause human behavior.

To illustrate the effects of beliefs, a prominent figure in the Christian history may be relevant. Martin Luther was an ideological and spiritual leader. Within his community, he "indirectly reorganized the religious institutions in his time and place by altering beliefs about the actual and ethical relationship between individuals and their god....Luther's directly affected social relationships by redefining the obligations and privileges of people in their religious roles. Luther's impact was especially broad and deep because the social organization immediately affected by him was dominant one that at the time exercised the function of legitimizing virtually all the rest of the culture and society" (Gold \& Douvan, 1997, pp. 161, 162). It can be argued that this historical fact clearly illustrates that the intra-psychological religious processes affect inter-psychological processes and may cause immense effects and massive results.

It is also vital to emphasize the difference between cultural psychology and cross-cultural psychology. Cultural psychology considers culture and psychology as mutually constitutive and deals with basic psychological processes as culturally dependant whereas cross-cultural psychology deals with psychological processes as if cultural impacting on their display but not on their basic way of functioning (Belzen, 2010, p. 41). 
The profound influence of culture on human cognition is obvious when we observe the effects of beliefs, metaphysical concepts, laws and these nonmaterial beliefs are joint properties of culture and individual cognitive structures -internalized norms that prescribe reality-status that may serve as selective cognitive functions (Pepitone, 1997). Presumably, beliefs embedded in cultures shape and affect psychology through cognitive structures.

When an individual interprets a meaning within a shared common world of culture, it is the 'reading' of others' minds according to cultural norms to understand the other's understandings and beliefs within the perspectives of the individuals' understandings of the world shared with them (Bruner, 1995, pp. 19,20). It can also be seen in these processes that there exists the interaction between intra-psychological and interpsychological processes. The sense of an aboriginal world 'out there', the sense of externality has deep origins such as ontogenic origins and its elaboration into adult folk psychological conceptions is supported by cultural beliefs and a language that keeps the distinction between facts and beliefs (Bruner, 1995, p. 20). The impacts of beliefs and environment on psychology are also evident in opinions. While describing dissonance and consonance, Leon Festinger and his colleagues argue that dissonance and consonance are relations among cognitions within the forms of beliefs, knowledge of the environment and knowledge of one's own actions and feelings (1958, p.158). Considering this fact, it is evident that beliefs affect psychology through cognition processes even in dissonance and consonance situations.

Similar to the role of beliefs in affecting the cognition and psychology, beliefs or religions also affect the value interpretation of the individual. In one formulation, religious values are a special class of values by their 'sacred' reference, whereas in another perspective, all values may have a religious characteristic or extent, being interpreted by the believer as expressions of an underlying ultimate reality (Williams Jr., 1958, p. 648). Interpretation of the individual can mostly be related with values which are presumably connected with beliefs.

Another interesting development is the emergence of recent studies regarding the relation between psychology and culture. Scholars have been conducting studies on how culture and neuroscience affect individual psychologies. The new field of 'cultural neuroscience' is defined as an "interdisciplinary field bridging cultural psychology, neurosciences and neuro-genetics that explains how the neurobiological processes, such as genetic expression and brain function, give rise to brain function, give rise to cultural values, practices and beliefs as well as how culture shapes neurobiological processes across macro- and micro-time scales" (Chiao, as cited in McDermott, 2017, p. 581). Cultural neuroscience research can be a promising field, also for studying the interactions between religions, neurobiological processes and psychology. 
In this section, the interconnectedness of beliefs and psychology has been evaluated. In order to understand the process better, we will need to return to analyze the relationship between the core phenomena. Before proceeding to evaluate further and deepen the focus on the research on psychology and religions, a brief illustration of the foundational essentials regarding the possible consistency of religion and science will briefly be presented.

\section{Science and Religion: A Synergetic Approach is Possible}

"What is the purpose of such momentary, uncertain and vacillating existence in this eternal, welldefined and never-ending world? ... This question invariably faces each individual, and everyone answers it in one way or another. It is the answer to this question that comprises the essence of all

religions"

Tolstoy, L. N. 1893 (as cited in Batson et al., 1993, p. 9)

"Science without religion is lame, religion without science is blind." Albert Einstein, 1941 (as cited in Verschuuren, 2017)

The phenomena of religion, science and the relations between various beliefs among these, have been the subjects of discussions for centuries. Throughout these discussions or researches, some of the arguments have been developed to find out the best option in designing the positions of science and theology for the sake of creating a more prosperous, innovative society or -in general- a better world. Whereas some of the discussions or declarations regarding the definitions, roles or importance of science and theistic beliefs have been designed to gain ally power within an arena of clashing interests. Some of the arguments on these issues have been developed by the interested parties to manipulate the masses in favour of various ideologies or interests.

In a historical perspective, it can be argued that the roots of science and religion competition can be found in Western ideological rivalities and the church policies. Prominent Jewish psychologist and former president of the American Psychological Association Abraham Harold Maslow in his statement illustrates how the needs on religion are normal but the approach of churches are wrong as follows (Maslow, as cited in Morgan, 2011) : “... it is increasingly clear that the religious questions themselves -- and religious questions, the religious yearnings, the religious needs themselves - are perfectly respectable scientifically, that they are rooted deep in human nature, that they can be studied, described, examined in a scientific way, and that the churches were trying to censor perfectly sound human questions. Though the answers were not acceptable, the questions themselves were and are perfectly acceptable, and perfectly legitimate. As a matter of fact, contemporary existential and humanistic psychologists would probably consider a person sick or abnormal in an existential way if he were NOT concerned with these 'religious' questions." Considering this 
fact, it can be argued that religion can very well be studied scientifically; probably the problem was with the old approaches of the church that caused the struggle.

Borchert (2017) argues that within the framework of the secular modern, belief has been favoured over ritual, and science over religion just as privileging of the Protestant concern on beliefs over Catholic ritualism. Also, post-positivist thinking, since the influential statements in Thomas S. Kuhn's The Structure of Scientific Revolutions, emphasizes that the subjective belief structures shape perception and knowledge (Cammack, 1995, p. 417). Today, "postpositivism has now replaced positivism as the accepted philosophy of how science is conducted. Given this change in approach, some see a closer connection between science and theology." (Seybold, 2007, p. 55). Consequently, considering the huge amount of philosophers and scholars, it can be now unwise to attain a totally privileged status to science. The philosophers are in search of obtaining optimal benefits from both science and religion can succeed only by ending conflicting quarrels and by focusing on constructive quests.

The Society for Christian Psychology, with its members of numerous scholars, scientists and psychiatrists, declares in their mission statement that "A Christian vision of human nature is shaped primarily by the Christian Scriptures, as well as Christianity's intellectual and ecclesial traditions." This group of psychologists highlights the importance of culture, traditions, belief and religion by emphasizing the importance of human sciences also: "However, a Christian psychology will also be critically informed by other relevant sources of psychological truth, particularly its own reflection, research and practice, but also the psychological work of other traditions (e.g., secular psychology), philosophy, human experience, and the other human sciences..." (Society for Christian Psychology, 2019). Considering this "theological" method of "science" as an example, it can surely be found acceptable to utilize various ideas from various beliefs while searching for scientific needs of different communities. Thus, the ideas of the writers having different beliefs may also be beneficial within the quest of developing enhanced visions and scientific perspectives.

Regarding the clash of ideas on the scientific and theological perspectives, it is easy to illustrate that there are radically different views of scientists on religion and beliefs. Whereas it is also easy to illustrate that there are radically different views of theologians on scientific theories.

An example from the science of psychology may be informative. The prominent scientists in psychology William James, Carl Jung, Gordon Allport and Sir Frederic Bartlett were theists, whereas Sigmund Freud and B. F. Skinner were among the atheist scientists (Jeeves \& Brown, 2009). The beliefs of scientists are very important because they significantly impact their world views. 
The two of the major figures of twentieth century psychology, Sigmund Freud and Carl Jung had contrasting views on what they called religion. For instance, according to Freud "religion was an obsessional neurosis, and at no time did he modify that judgement". In contrast, Jung stated that "it was the absence of religion that was the chief cause of adult psychological disorders" (Spinks cited in Jeeves, 2008). These diverse perspectives clearly illustrate that the stark contrast in beliefs (or unbelief) between the abovementioned scholars may result in grave consequences of developing scientific arguments that are cast in different moulds.

On the other hand, scientism is believing that science covers all there is; and Verschuuren $(2017$, pp. 675, 676) opposes this idea by using psychologist Abraham Maslow's prominent saying "if you only have a hammer, every problem begins to look like a nail". Verschuuren argues that there would be no room for religion, if science covers all; and he suggests stopping idolizing 'scientific hammer'. An individual with wisdom must be aware that some of the ideologists can be utilizing 'scientific hammer' whenever they need, whether it is appropriate to use it or not.

Today, as before, scholars have various arguments questioning or thinking on the reliability of scientific truths and findings. Nowadays, big attention has been directed to the scientific questioning of the reality, as if the reality may just be a hallucination. Recently, a neuroscience professor, Anil Seth, of Sussex University declared his arguments on the explanation about why reality may just be a hallucination (Attala et al., 2018). Similarly, the results of a recent quantum experiment suggested that there is no such thing as objective reality, no freedom of choice (MIT Technology Review, 2019). Also, recently physicists' theory predicts that the future might be influencing the past (Mcrae, 2018). Interestingly, a recently revealed evidence illustrates that one of the most famous experiments in the history of psychology, Stanford Prison Experiment, was done under the influence of the experimenters and these new evidences suggest a shockingly different explanation regarding behavior and psychology (Van Bavel et al., 2019). Considering these scientific theories and arguments, one can ask what is the credibility of previous scientific findings, created before knowing about these issues? The credibility of scientific knowledge is also depends on the level of truth that it can offer. Here, a kind of weakness regarding the scientific knowledge production process may be seen evident.

It must be remembered that the scientists generally use the principle called: 'Occam's razor'. This principle is suggesting to cut away any excessive presumptions to develop the simplest feasible solution to any problem and some fans of neuroscience eliminate consciousness and the self similarly (Lahti, 2019). But in fact, the inventor of this proposition, William of Occam was a man of faith and would have been shocked at his idea being handled to slide off parts of his worldview (like God) that 
he held most beloved (Lahti, 2019). That said, scientific research may not be relevant if the research cuts away causal agents and factors. Similarly, it should also be noted that "Scientific theories are never 'proven' beyond all doubt. Conclusions in science are always incomplete, tentative and subject to revision based on new evidence." (Seybold, 2007, p. 56). On the other hand, religion may also be used for illegitimate, amoral or wrong aims, targets. Religious leaders may deceive and religious laws or principles may be implemented to legitimize harmful and toxic behavior (Newberg, 2010, p. 204). Being cautious about both scientific and religious influencers, appears to be the safest option to produce scientific knowledge.

There are various kinds of aspects affecting the reliability of 'scientific findings'. Hood (2012) argues that psychology of religion has been influenced by wealthy persons and foundations ever. Moreover, "several psychology departments in America are housed within Universities that are sponsored by churches and guided by mission statements with explicitly religious objectives" (Reber, 2006, p. 193). Whereas in the field of neurotheology, Weker (2016, p. 61) shares the critics' arguments such as the analyses of findings, the experiments themselves and research projects lack of objective interpretation as the result of ideologically orientation. In general, it can be argued that scientific studies and findings may have been subject to various influence, control, manipulation policy and strategies by some global and glocal institutions, charities etc.

Also, scientific world has another disturbing problem as prominent scientists and revolutionary psychologist Franz Fanon points out. Fanon famously challenged scholars and philosophers with a call for critical task of decolonizing mainstream intellectual production (Adams et al., 2015). These kinds of facts partly overshadow scientific knowledge's superiority and make one question any kind of information and indoctrination.

In this research work, the aim is to evaluate the previous ideas and researches to discover the connections between the phenomena of science and religion. Since the wide scope of various ideas on various sub-fields related with this topic, we will narrow our research to study the relation of new brain sciences, psychology and religion.

\section{Studying Psychology and Religion}

Religion is defined as "a system of beliefs in divine or superhuman power, and practices of worship or other rituals directed toward such a power" (Argyle \& BeitHallahmi, as cited in Fontana, 2003, p. 7). It is systematic and this aspect of religion makes it more understandable and relevant for cognitive structuring of mind by religion. 
The cognitive structuring of religious belief formation is an important study field. Daniel Batson and his colleagues describe the stages of cognitive restructuring as the results of reality transformation processes offered by religious experiences as (Batson et al., 1993, p. 115) : "-preparation- unsuccessful attempts to solve the problem by using the old cognitive structures; incubation- giving up the attempt to solve the problem; illumination- emergence of a new cognitive organization that enables the individual suddenly to see the components of the problem in a new way, permitting solution; and verification- testing the functional value of the new solution."

Consequently, 'orthodox' psychology itself has been experiencing noticeable transformations such as 'spiritual turn', which is re-consideration of topics related to religion and spirituality, seen in the fields of psychology and psychiatry (Gripentrog, 2018). Mainstream psychology scholars and professionals can be invited to understand this fact and be tolerant through their scientific studies and works.

In a totally different perspective; a different kind of relationship between science and religion, the hostility of Scientology Church against psychiatry can illustrate some interesting understandings. The Church of Scientology accuses psychiatry of being; a crude anti-religious substitute for religion, enemy of religion seeking to infiltrate irreligion into education system (Aldridge, 2008, p. 56). Moreover, arguing that there are so many mental illnesses among psychiatrists themselves, the Church also campaigned aggressively against medical use of psychotropic drugs such as Prozac, and electroconvulsive therapy and psychosurgery (Aldridge, 2008, pp. 55,56). These generalizations are not approvable but an educated and trained psychiatrist may also abuse human rights with brutal and inhuman behaviors. The American Psychiatric Association (2007) condemned criminal Serb leader psychiatrist Dr. Radovan Karadzic for his brutal and inhuman actions with particular offense, urgency and horror because by education and training, Dr. Karadzic claims membership in psychiatry profession.

Regarding the relation of science and religion, an inspiration from the book $A$ History of the Warfare of Science with Theology in Christendom, (1896) by the founder and first president of Cornell University and former president of the American Social Science Association, Professor Andrew Dickson White may provide historical insights. While criticising John W. Draper the author of the book The Conflict between Science and Religion, White (1896, p. 9) says: "He regarded the struggle as one between science and religion. I believed then, and am convinced now, that it was a struggle between science and dogmatic theology". Inspired by White, it can be argued that the transformation from struggle to synergy may be established by removing dogmatic, biased or manipulative influences, interpretations from both theology and science. 
Moreover, it is also important to focus studies on transpersonal psychology. Both Antony Sutich and Abraham Maslow identified transpersonal psychology as the "fourth force" approaching at the end of an upward progress, with behaviorism as the first force, psychoanalysis as the second and humanistic psychology as the third (Gripentrog, 2018).

In conclusion of this chapter, a brief reminder regarding the ongoing relations between psychologists and religion will be emphasized. Currently, it can easily be argued that some of the psychologists are mostly detached, distanced and keeping their professions apart from religion. But there are scientific studies arguing that these psychologists must change their approaches. One example is Jeffrey S. Reber, an associate professor of psychology and interim chair of Criminology at the University of West Georgia. To change the approaches of these kinds of psychologists, distanced apart from religion, the initial step may be what Reber (2006, p. 202) suggests: "one step secular psychologists might take toward increased dialog and resolving the problems their current anti-religious form of secularism creates is to practice secularism in the way it was originally understood by critically examining all dominating, unexamined assertions of authority and truth, including its own". Lastly, Nissen et al. $(2018$, p. 2) argue that on the current global horizon, the Eurocentric notions like secular and religion are not relevant, these must be re-negotiated and this proceedings has also affected psychiatry by a considerable change in the way psychiatry considers and approaches the religious becoming distant from the traditional, antagonistic perception, to a more nuanced and inclusive approach.

\section{Psychology and Religion \& Psychology of Religion}

The Psychology of Religion and Spirituality Division of the American Psychological Association (APA), was first founded as a result of the American Catholic Psychological Association's consideration to support Catholics to engage in the science and the profession of psychology namely Psychology of Religion and Spirituality (Hood, 2012, p. 7). Interestingly, one of the fathers of modern psychology, Gordon W. Allport was an early member of Journal for the Scientific Study of Religion (Hood, 2012, p. 12). Considering these facts, it can be argued that the world's most prominent institution the American Psychological Association, does not put barriers against people's quests on scientific studies on religion but promotes it.

Following the attempts of the Catholic Associations, due to the cultural affect of psychologists studying German experimental model, the American psychology of religion emerged as a psychology of North American Protestant Christianity (Hood, 2012, p. 8). This reminds us the fact that the psychology was transformed 
from speculative philosophy to a natural science thanks to the conduction of psychological laboratory experiments in 1879 by Wilhelm Wundt (Hood et al., 2009, p. 478). Wundt suggested that physical phenomena analysed by the natural sciences and the rules of these phenomena do not dispute the qualitative constituents of life concerned with psychology (Wundt, 1912, p. 183). Also, Wundt argued that the psychology should not only accept personal psychic processes as its objects, but also issues such as language, ethics, customs, society and religion (Belzen, 2010, p. 10). The Zeitgeist shapes the research trends within the fields of psychology and the rise of post-secular developments have been fuelling more and more interest in the psychology of religion. Psychology of religion field must somehow be wisely designed to enrich and benefit from both the contributions of scientific rationality together with the contributions of religion.

One of the pioneers in the field of psychology was William James (1842 - 1910). William James rejected the Sigmund Freud's declaration that religious belief was 'perverted sexuality'; he argued that, to understand religion, one must consider the immediate content of the religious consciousness (James, as cited in Hood, 2012, p. 10). James had provided inspiration to the other researchers by championing the immediate content of religious consciousness. James (1902, p. 488) argues that the science of religions may not be an equivalent for living religion by using AlGhazzali's statement as: "to understand the causes of drunkenness, as a physician understands them, is not to be drunk". And considering the inner difficulties of the science of religions, James (1902, p. 489) suggests that "a point comes when she must drop the purely theoretic attitude, and either let her knots remain uncut, or have them cut by active faith". It can be argued that positive psychology field studies must be accomplished with the awareness of this point and the need of utilizing faith.

Belief and religion have always been attracting interests of scientists and believers who have been benefiting from science. A Protestant Pastor, Gustav Theodor Ferdinand Franz Vorbrodt co-founded the German 'Journal for the Psychology of Religion' whereas prominent psychologist, Stanley Hall ventured to use psychohistory to make a psychohistorical study of Prophet Jesus in his work named Jesus, the Christ, in the light of Psychology. (Belzen, 2010, pp. 34, 107). These examples may also illustrate the attempts to harvest the understandings that religious knowledge may bring to the modern science of psychology.

Similarly, the eminent psychologist Carl Jung has been emphasizing the crucial functions in the psychology of individuals. Apart from Jung's scholarly contributions, his personal insights also provide inspirations. In his autobiography, Jung declares his personal relationship to God as: "I find that all my thoughts circle around God like the planets around the sun, and are as irresistibly attracted by Him. I would feel 
it to be the grossest sin if I were to oppose any resistance to this force" (Jung, as cited in Morgan, 2011). Jung also strongly emphasizes that it is crucially necessary to construct a religiously-based worldview, ethos, a religious mooring in order to re-align with the 'collective unconscious' which infuses all of the conscious and unconscious thoughts, actions and dreams (Morgan, 2011). This prominent German scientist's evaluations and thoughts clearly illustrates that the supporters of the ideology that claim strict division and separation of scientific thought and religious thought may be wrong. Scientifically acceptable, credible examples of religion and science interactions can easily be found.

The research of the former Duke University psychiatrist David B. Larson (1996) illustrates that "Nearly one-half of the members of the American Psychiatric Association and the American Psychological Association report a belief in a God or higher power and one-third of clinical psychologists and two-fifths of psychiatrists agree with the statement, 'My whole approach to life is based on my religion'" (Larson, as cited in Reber, 2006, p. 196).

To proceed to a better understanding, a definition may be inspiring. Psychology of religion is neither 'the dialogue between psychology and theology', nor 'religious psychology'; the objective of psychology of religion is to utilize psychological instruments such as theories, concepts, insights, methods and techniques to analyze and comprehend religion in a scholarly manner (Belzen, 2010, p. 4). Psychology of religion is a very important field of study because of the potential benefits that these studies may provide. According to recent studies, religion serves as producing neuropsychiatric benefits in the forms of preventative, curative or both (Bhalla, 2018). Similarly, a Psychology Professor, David DeSteno (2019) in his article, titled; What Science Can Learn From Religion argues that some religions provide tools and techniques to support secular interventions such as; reducing suffering, increasing self-control, combating addiction, forgetting vengeance. DeSteno also suggests that hostility toward spiritual traditions possibly be hindering empirical research. Considering these facts, it can be argued that being ignorant on the issues such as culture and religion will diminish the capacity of the scientists, or specifically the psychologists by depriving them from very important tools and agents.

\section{More on the Psychological Benefits of Religion}

After the end of the Middle Ages, the psychiatric care in the mid-nineteenth century, became to be known as 'moral treatment' with having significant religious influences; whereas the collaboration between religious and mental health professionals, mostly ended as a result of the theories of Freud and others (Koenig \& Larson, 2001). Even though those previous studies appeared like proving the common clinical doctrine 
that religion worsened mental health, a greater amount of up to date researches using superior methodologies seem to proclaim quite the opposite, i.e. that religious attachment is mainly related with greater well being, slighter depression and anxiety, more social support, and less substance abuse (Koenig \& Larson, 2001).

The benefits of religion on psychiatry can be seen in Islam as an example. According to the American Psychiatric Association (2018) some of the benefits of 'Islamic Religiosity and Mental Health' are defined as: “Islam promotes healthy behaviors: emphasis on personal hygiene, instructions against alcohol and substance use, prohibition of sexual promiscuity, recommendation to breastfeed, strong sense of community, recommendation to engage in daily reflective practices, religiosity is predictive of better family functioning, observing daily prayers is associated with reducing depression" These findings are also in consistency with the meaning of the Creator's words : "....without doubt, in the remembrance of Allah, do hearts find tranquillity.” (Quran, 13/28).

After illustrating the significant number of scientific literature that connects religion and spirituality to physical and mental health, Pargement and Hill (2003) argues that religion is connected to physical; and as mental health and as psychologists get closer to religious and spiritual life, they are beginning to understand why. Similarly, emphasizing the increasing levels of chronic stress-related disorders throughout the world, Saniotis (2015) argue that the practice of Islamic practices of salat and dhikr may help preventing chronic disease and foster psycho-physical well-being. On the other hand, a research on 138 refugees from Kosovo and Bosnia illustrated that their optimism was positively related to religious coping (Ai et al. cited in Mishra et al., 2015).

According to some other recent scientific researches, religion is found to be providing happiness. Myers (2000) found that "in a nationally representative US Gallup poll, respondents were twice as likely to be in the "very happy" group if they had reported religious faith as being most important, as opposed to least important (cited in Prieto \& Miller, 2018, p.1). Also, as the result of their research, Rosmarin, Pargament, \& Mahoney (2009) found that "trust in God was associated with greater happiness and lower levels of anxiety and depression for Jewish participants" (as cited in Prieto \& Miller, 2018, p. 2). Similarly, regarding suicide; in the American Psychiatric Foundation (2010) practice guideline, it is stated that: "in general, individuals are less likely to act on suicidal thoughts when they have a strong religious faith and believe that suicide is morally wrong or sinful." Moreover, a recent national survey among American citizens illustrated that $79 \%$ of the sample prayed for healing of themselves and $87 \%$ had prayed for the healing of other people (Levin, as cited in Oman, 2018, pp. 45,46). 
There have been various scientific findings that illustrate the positive effects of religion on health and it is wiser not to discuss all of them one by one but to illustrate the general result. A recent research titled: Religion's Relationship to Happiness, Civic Engagement and Health Around the World, illustrates the findings of a previous research by arguing that "many of the studies that have been published in the past 30 years have found that religious people tend to live longer, get sick less often and are better able to cope with stress" (Koenig, as cited in PEW Research Center, 2019).

Moreover, the most promising study field within psychology of religion appear to be religious coping studies. Psychology Professor Kenneth I. Pargament's methods, theories and studies have been championing of and providing inspiration for numerous other studies. Religious coping, according to Pargament (1997) is; the efforts to comprehend and deal with life stressors in ways related to the notions of God, divinity, higher powers and also other aspects of life that are associated with the divine (as cited in Fadilpašić et al., 2017). On the other hand, Harold G. Koening (1994) defines religious coping as "the dependence on religious belief or activity to help manage emotional stress or physical discomfort" (as cited in Lager, 2006, p. 33).

Without doubt, there have been various researches and various implementations regarding the utilization of religion in improving and strengthening health of individuals and communities. Illustrating all of these benefits is beyond the scope of this section. But it is vital to emphasize that these benefits will probably be directed pragmatically or abused by wrong policies influenced by various lobbies or institutions.

Psychoanalyst Robert Samuels, in his recent book Psychoanalyzing the Politics of the New Brain Sciences, argue that some of the evolutionary psychologists' works and neoliberal discourses have been prepared with desires to discredit social sciences, psychoanalysis, cultural theory, progressive parenting and welfare state programs by suggesting that we are determined to act in certain programmed ways (Samuels, 2017, p. 138). Samuels further claims that the collusion of works by governments, universities, medical doctors and pharmaceutical companies have unintentionally been converting science into a neoliberal market in a recent kind of Social Darwinism (Samuels, 2017, p.115). The neoliberal society is illustrated as a system where social discontent is medicalized, people are pushed to compete for scarce resources in unfair societies and for succeed in the competitive rat race, people are directed to drugs (Samuels, 2017, p. 138). Also, in the field of biotechnology, there are questions on human genome editing researches. Cathomen et. al (2019) ask if the human genome editing race is "loosening regulatory standards for commercial advantage?" Considering these facts, scientists must beware that this kind of transformations of sciences into metamorphosed liberal indoctrinations by the unintentional industrial complex may also affect the studies on religion and science interactions. 
So far, this section has briefly focused on some psychological benefits of religion with precautions on neoliberal agenda affecting new brain sciences. The following sections will focus on a relatively new brain sciences; neurotheology and cognitive science of religion. The aim will not be to claim that we are determined to act in certain programmed ways. The aim will be searching for any possibilities that neuroscience may contribute to our understanding regarding the interaction between religion and psychology.

\section{How to Interpret \& Utilize New Brain Sciences:}

\section{Neurotheology}

"The Decade of Brain" was declared by U.S.A. Congress and extended research funding for neuroscience impressively and rapid developments of cognitive neuroscience resulted in convergence of cognitive psychology, comparative neuropsychology and brain imaging techniques such as magnetic resonance imaging (MRI), positron emission tomography (PET), functional magnetic resonance imaging (fMRI) and transcranial magnetic stimulation (TMS) (Jeeves \& Brown, 2009).

Although the very first emergence of the term neurotheology originates from James Ashbrook's works in 1984, Aldous Huxley previously mentioned about neurotheology in the utopian novel Island in 1962 (Kyriacou, 2018, p. 2). After the evolution process within the discipline, various definitions and arguments transformed the general view on what neurotheology should address.

The meaning, scope and validity of the term neurotheology have been subject to discussions. Norman and Jeeves suggest that the term neurotheology is an "unfortunate term in many ways, not least of which is that many so-called neurotheological investigations contain questionable neurology and/or theology" (2010, p. 239). It can be argued that this study field also contains various researches without a wellconstructed argument or reaching to a clear destination and meaning.

Also, considering the arguments against the neoliberal discourse production processes, it is found appropriate to select the recent definition of neuroscientist Andrew Newberg. Newberg (2016, p.18) defines neurotheology as a multidisciplinary field of research, in search of comprehending the relationship precisely between the brain and theology, and more broadly, between the mind and religion. Newberg's ideal neurotheology definition requires the perspective of an integrated approach, 'two-way street' approach between science and religion, integrating the best of what can science offer with what religion and spirituality offer (2016, p.18). The 'neuro' component of neurotheology should be considered as including psychiatry, psychology, cognitive neuroscience, genetics, endocrinology and some other micro- 
and macro- perspectives of the neurosciences (Newberg, 2010, p. 45).This definition of neurotheology appears really comprehensive, and the aim within this definition seems very functional and useful.

With this perspective, neurotheology will be practicable in developing understandings and strengthening the mental health of individuals. Increased understanding of neurotheology allows counselling professionals to develop unique lens for accurate evaluation and failing to attend neurotheological insights will limit their capacity to evaluate the clients' holistic wellbeing (Dixon \& Wilcox, 2016).

Senior Research Professor Kenneth J. Gergen (2010) argues that, at the time that the causes of human behavior are reduced to the cortical level, concentration on socio-cultural processes begins to conclude. Gergen (2010) shares and emphasizes the arguments of Professor Emily Martin who argues that; "social scientists should unite in 'opposition to a position in which the dike between nature and culture has been breached, and all that [we] call culture has been drained through the hole and dissolved in the realm of neural networks" " (2010, p.576). When Francis Crick (1994) argued as: "You are nothing more than the behavior of a vast assembly of nerve cells and their associated molecules...", Jeeves \& Brown (2009) analyzed this theory as "nothing but ink strokes, carrying no message" and argued that it is impossible to simply reduce individual behavior to the explanations of biological science and to reduce biological science to physical science. Professor Gergen also illustrates that biases in neuropsychology studies have led the critics to regard neuropsychology as a type of cultural imperialism (2010, p.7). Considering the neoliberal discourses and targets described in the previous section, Gergen's arguments leads one think that it is crucial to beware about the possible unscientific agendas of the some 'scientists'.

Neurotheology utilizes neuroscience and focuses on functions and structures of brain and neurons. To describe better, a brief description of how brain and its substructures operate will be presented. Ryan McIlhenny (2010: p. 32) puts it as: "first, the basic unit that carries or sends messages to the various parts of the brain for thought and action is the neuron. Branch-like axons carry messages from neurons; dendrites receive those messages. Neurons travel through the various lobes in order to produce basic and more advanced conceptualizing for articulation and action. Next, the cerebral cortex is divided into two hemispheres, the left and the right. The former is associated with more localized, systematic, and detailed thinking, while the latter looks at the whole. The two coordinate the forest and the trees. The hemispheres of the brain are further divided into four lobes - temporal (language, memory, and conceptual thought), frontal (problem solving and muscle activity), occipital (sight), and parietal (perceptual and bodily orientation)". This description is presented just for creating an idea about the topic. 
On the other hand, neuroscientists estimate that the number of neurons in an individual's nervous system is between 100 billion and 1000 billion and the number of possible ways these neurons can be interacted is speculated to be more than the number of atoms in the universe (Seybold, 2007, p. 7). The brain is complex and the descriptions are surely missing. The developments regarding the brain researches widen the scope of studies. Moreover, different studies imply the importance of different regions of the brain and scientific imaging technologies are not capable enough to provide the certain truth about brain operations. Nevertheless, studies, researches provide clues and some kinds of insights.

Interestingly, psychedelic drugs such as peyote cactus, psilocybin mushrooms and marijuana have been used to spur religious practice since the emergence of history (Wasson, as cited in Batson et al., 1993). Daniel Batson (1993) and his colleagues suggest that psychedelic drugs, mediation, religious language and music have power to facilitate religious experience. Scientific research illustrates that psilocybin causes powerful spiritual experiences and drugs such as opiates, lysergic acid diethylamide (LSD) and stimulants can occasionally motivate spiritual experiences whereas some other affective agents that may be related with religion are: gamma-amino butyric acid, dopamine, beta-endorphin, n-methyl d-aspartate, serotonin, acetylcholine, melatonin, dimethyltryptamine, peyote, ketamine, phencyclidine, nitrous oxide (Newberg, 2010). The chemicals that influence an intricate mixture of interactive brain systems fall into one of three groupings: tryptamines, phenethylamines and ergolines (Jeeves \& Brown, 2009, p. 92)

A theory of predicting processing by Elk \& Aleman (2016) suggests that four brain mechanisms to focus on which play key roles: temporal brain areas are related with religious visions and ecstatic practices, multisensory brain areas and the default mode network are participating in individual transcendent experiences, the Theory of Mindnetwork is related with prayer and attribution of intentionality. On the other hand, approximately two decades earlier, Ashbrook (1997, p. 308) argued that accurate and precise functional localization is uncertain because of various grounds such as anatomical overlaps, shared neuronal elements with neural structures that interpose divergent purposes. On the other hand, recently neuroscientists discovered a new kind of brain cell in humans which have never been seen in the brains of mice and other animals that have been used to model human brains in experiments (Science Daily, 2018). Also considering that neurons, neurotransmitters, multisensory brain areas and other physical elements may be the same in various peoples, but these physical elements can not provide a person to have religious beliefs.

It should also be noted that the size of the universe is calculated in terms of light years, the distance light travels in a year that gives an estimate of the universe's size 
at 13.7 billion light years (Fleming, 2016). While size of the universe seems to be astronomically large, the sizes of persons compared to their component atoms make people seem huge (Fleming, 2016). The physical structure of an individual is extremely complex to define certain and precise conclusions about psychological processes.

Neurotheologists search the mechanism of religious practices within neurobiological agents and operations that take up physical space in time, whereas transpersonal psychologists explore the mechanism in physical structures and proceedings that, similar to the experiences they convey, do not exist extended in space or basically exist in time (Cunningham, 2011, p. 241).

Neurotheology studies benefit from brain imaging technologies such as functional magnetic resonance imaging (fMRI) and electroencephalograph (EEG). A recent research by using these technologies illustrated that "religion/spirituality beliefs may affect microstructure in brain regions associated with religion/spirituality, conferring resilience to depression among high-risk individuals", meaning that; "individuals at high familial risk for depression typically share a neural signature that is similar to the one that can be found in those at low familial risk, as long as they take religion/ spirituality beliefs as highly important" (Xuzhou et al., 2019, pp. 1,11). These kinds of researches provide helpful insights regarding the role of religion in individual psychology and health.

A different kind of useful utilization of neurotheology can be obtained by getting inspirations from neurodecolonization studies. The aim of neurodecolonization is to delete old, ineffective brain networks that support destructive thoughts, feelings, memories and behaviors that occur for most people and the colonized, while encouraging the growth of new beneficial brain networks (Bird, 2005). Consequently, it can be argued that neurotheology studies may be utilized for the decolonization of the minds.

To sum up, there are various essays, researches and findings whether they stem from scientific approaches or constitute some scientific contributions to the field. The most important fact is neurosciences may also be utilized to develop the "twoway street' theories and understandings that will contribute to enhance religion and psychology interaction processes.

After the brief evaluation of neurotheology, in the next chapter, the evaluation will be focused on a similar field of brain science, cognitive science of religion.

\section{Cognitive Science and Religion}

The roles of cognitive science in affecting psychology have been illustrated in various paragraphs above. Being cautious about; not dissolving social sciences and culture in the realm of neurosciences, and bewaring about the threats such as 
transformation of science into a neoliberal market as a form of social Darwinism, it will be our aim to quest for the ways that cognitive science may provide contribution to religion and psychology.

Cognitive Science of Religion can be defined as a multidisciplinary research process in which the scholarly ideas on religion, experimental psychology, anthropology and evolution cross-fertilize to understand how human cognitive architecture has allowed religious concepts to be possible and easy to expand inside and over cultures in considerations with both cognitive and socio-cultural processes (Pyysiäinen, 2014, pp. 30, 31). This definition, constructed with inspiration from Pyysiäinen, sounds really comprehensive and the aim appear to be very helpful, functional and useful.

In his article titled; Neither Friends, Nor Enemies, Léon Turner (2014, p. 154) mentions about some cognitive science of religion theories that assume various "beliefs in gods to be mere by-products of human cognitive evolution" however he also emphasizes that "some (perhaps most) of cognitive science of religion's widely accepted cognitive explanations of various aspects of religion leave plenty room for alternative, non-contradictory sociohistorical explanations, some clearly do not." Inspired by the evaluations of Turner (2014, p. 169), it can be argued that cognitive science of religion should not be downgraded to wrong interpretations of mere evolutionary beliefs but a coherent approach with humanistic and social scientific dimensions of religion can be constructed.

It is also an important fact that some of the scientists choose to ignore the fact that an explanation of evolution which can also be acceptable and in consistence with religious thoughts. It is discovered that "a large number of Americans endorse some form of theistic evolution -an alternative to evolution claiming that God is responsible for evolution" (Gallup Poll, as cited in McPhetres \& Nguyen, 2018). This kind of perspectives can be diversified within variations that may be coherent with both science and religious thoughts.

Similarly, cognitive science of religion can serve for understanding the human psychology by evaluating cognitive structures as the mechanisms created for understanding the Creator and religion. Clark and Barrett (2011) argue that there appears to be good empirical reason, presented by cognitive scientists working on religious thought to believe that we have a maturationally natural 'god-faculty'. Considering the research evidences of cognitive science illustrating that individual minds are characterized not only by few basic faculties like memory, perception and reason but also by adaptive mechanisms engaging in nonconscious conceptual activities, cognitive science of religion research points to the fact that humans may be endowed with maturationally natural 'god-faculty' or 'religious-faculty' (Clark and Barrett, 2011). 
Instead of trying to instrumentalize cognitive science of religion for anti-religious efforts and use Daniel Dennet's (2006) essay to 'break the spell' or Richard Dawkin's (2006) essay to dismiss religious belief as delusional, inspired by Jong (2013), it can be argued that using kalām, cosmological arguments of William L. Craig (1979) can be more promising and productive thanks to its suggestions as: "God as the first cause of the universe, of its initial conditions and concomitant laws of nature, God would, by the transitivity of causation, be the ultimate cause of all subsequent entities and events, including the evolutionary, developmental, cognitive, and indeed contextual" (Jong, 2013, p. 528). In search of cognitively appealing accounts of origins, De Cruz and De Smedt's argument can also be inspiring: "Intuitions about causality underlie the inference of an external cause of the universe, whereas predispositions towards agency make God a natural candidate for this cause" (as cited in Mantovani, 2018, p. 152). These kinds of understandings can be related with considering the brain and cognition not as the real source but just the mediator, as Cunningham argues; the brain may not generate religious cognition and emotions but instead mediates them (Cunningham, 2011, p. 235).

Implicit, intuitive patterns of thinking, together with cognitive and social resources, results in formulation of religious concepts, behavioral patterns and to construct a broad empirical and theoretical base required for explaining religion can only be accomplished by coordinated and interdisciplinary effort (Whitehouse, 2008).

On the other hand, it should be noted that the individual's failures in attitudes may also prohibit the development or progress of his / her knowledge and understanding. Some of the cognitive mechanisms of some individuals may not be working properly. Scientists have been discovering that behaviors may affect cognitive capabilities of individuals. According to Wissenbacher (2015, p. 46) “....recent scientific discoveries have begun to reveal that the brain can change through the activities it performs, essentially rewiring itself through experience". These behavioral results may be consistent with what the Creator declares: "Have you seen the one who has chosen his /her desires as his /her God? Allah has knowingly caused him / her to go astray, sealed his / her hearing and heart and put a cover on his / her sight. Who then can guide him / her besides Allah? Will you then not take heed?" (Quran, 45/23).

There have been various empirical researches and implementations, within the limited scope of this essay, only brief information regarding cognitive behavioral therapy will be illustrated. Cognitive behavioral therapy, which combines philosophy, cognitive science and behavioral theories, is one of the most influential models in psychotherapy and it explores the mind's cognition to develop abilities against suffering from negative thoughts and avoidant behaviors (Varvatsoulias, 2013: 62). Transformation of personal schemas, meanings and thinking errors such as; black- 
and-while thinking, filtering, mind reading, catastrophising and overgeneralising can be replaced by cognitive restructuring to construct positive thinking patterns (Varvatsoulias, 2013, p. 67). Cognitive science of religion appears to a have very rich toolbox in order to develop diverse proposals and approaches to various psychological aspects and issues. There is a need for further research using appropriate methodology developed by combining the contributions of belief, culture and science.

"To educate a man in mind but not in morals is to educate a menace to society"

Theodore Roosevelt

\section{Conclusion}

In the emergence of the first book with the title Psychology, and in the approaches of the very first modern psychologists such as William James, Carl Jung, Gordon Allport and Frederic Bartlett, the traces of religious thought is evident and positively related with science. The problematic policies of the Catholic Church led to the protestant reformation, and the ideas of reformation philosophers influenced some scientists to distance themselves from religion. Nevertheless, some scientists, realizing that whole belief systems can not be blamed for the problematic approaches of the church, developed scientific approaches that were in harmony with religious though. The Counter reformation ideologists and post-positivists can be the examples of attribution of roles to the religious thoughts in science. In some scientific communities, the reunion of scientific thought and religious thought dates back to the very early periods of the reformation. On the other hand, for some scientific communities, the distance between religious thoughts and scientific approaches has been widening. Even today, some neuroscientists as well as cognitive scientists are struggling to downgrade psychology to just being the processes of brain cells and chemical reactions.

This essay has illustrated the coexistence of religious and scientific knowledge existing from the emergence of modern psychology. The very first scientific definitions and arguments regarding modern psychology have been explored to emphasize the coherence between science and religion. The eminent theist scientists and their theories, arguments and approaches illustrate that the synergy of religious and scientific thought may be utilized to develop more useful, functional and inspirational knowledge. Theoretical contributions and practical implementations can be derived from these previous approaches and theories to reevaluate the position of belief in psychological science. 
Also, arguments related to the misuse, misinterpretation or misinformation of scientific and religious knowledge procesess, influences and effects have been recalled to illustrate the necessity on being cautious.

Also, the core and the vast amount of this essay is composed of arguments and discussions stressing the contributions of religious elements to science and psychology. Religion is embedded in science and with constructive scientific work, may be utilized to enhance knowledge. Similarly, scientific approaches may enhance the roles and contributions of religions to the lives of individuals and societies.

On the other hand, to be more scientifically credible, most of the brief examples and views analyzed within this essay were chosen from prominent scientists' and, more specifically, psychologists' findings. With the help of these scientific arguments, a new vision construction of a new 'ultramodern' psychology is designed which puts culture, beliefs and religions as an integral part of contemporary understandings of psychology.

Again some arguments regarding the commercialization of research targets, transformation of science into neoliberal market discourses leading to some kinds of social Darwinism, or regarding the influences of some sponsors, some foundations, some leaders and various neoliberal agendas have been shared to illustrate the necessity to be cautious.

Moreover, the importance of research on the topics such as; intra-psychological processes and inter-psychological processes, positive religious coping, neurodecolonization, cognitive restructuring for developing positive thinking patterns, dialogue between scientific thinking and theological thinking have been examined.

This essay has been focused on briefly tracking the status of religion within the development of modern psychology and emphasizes the functions and positions of religion in psychology. To do this, the interdisciplinary connections between psychology, beliefs, cultural psychology and religion have been evaluated. The possibilities, historical developments and opportunities for the future of religion and psychology have been evaluated to emphasize the necessity of enhancing the interaction between religion and psychology. Inspiration for possible future projects and researche has been developed by evaluating approaches benefiting from the new brain sciences of neuroscience and cognitive science.

In conclusion, this research paper has presented the possible theoretical and practical contributions that can be achieved through constructing a comprehensive science vision by illustrating the historical connections and interactions between psychology, psychologists, beliefs and religions. There have been various constructive ideas 
and approaches that may enlighten the development of the future role of religion in psychology research and approaches. The argument of this essay is: for building future perspectives on psychology, religion can possibly provide a historical and modern toolbox and various other contributions. Ultramodern psychology must be reformed by utilizing new brain sciences and by considering the roles of cultures, beliefs and religions. The future perspectives for science must also include being cautious about the transformation of science into a neoliberal market as well as the erasure of culture, belief and religion by the realm of neural networks.

\section{References}

Adams, G. \& Dobles, I. \& Gomez, L. H. \& Kurtiş, T. \& Ludwin E. Molina (2015). Decolonizing Psychological Science: Introduction to the Special Thematic Section. Journal of Social and Political Psychology, Vol. 3(1), 213-238, doi:10.5964/jspp.v3i1.564

Ai, A. L., Peterson, C., \& Huang, B. (2003). Research: The effect of religious-spiritual coping on positive attitudes of adult Muslim refugees from Kosovo and Bosnia. The International Journal for the Psychology of Religion, 13(1), 29-47.

Aldridge, A. (2008). Religion in the Contemporary World, A Sociological Introduction, Second Edition, Polity Press.

Allport, G. W. (1935). Attitudes. in C. M. Murchison (Ed.), Handbook of Social Psychology, (pp. 789-844) Worcester, MA: Clark University Press.

Allport, G. W. (1966). Religious Context of Prejudice. Journal of the Scientific Study of Religion, 5, (pp. 447-457)

Allport, G. W. (1985). The Historical Background of Modern Social Psychology. in G. Lindzey \& Elliot Aronson (Eds.), The Handbook of Social Psychology, Third Edition, vol. 1, (pp. 1-46), Newberry Award Records Inc.

American Psychiatric Association. (2007). Position Statement: Resolution Condemning the Role of Psychiatrist Radovan Karadzic in Human Rights Abuses in the Former Yugoslavia. Council on International Affairs, Committee on Human Rights, Retrieved from https://www.psychiatry. org/File\%20Library/About-APA/Organization-Documents-Policies/Policies/Position-2007Karadzic-Human-Rights-Abuses.pdf 16.06.19

American Psychiatric Association. (2010). Practice Guideline For The Assessment And Treatment Of Patients With Suicidal Behaviors, Retrieved from https://psychiatryonline.org/pb/assets/raw/ sitewide/practice_guidelines/guidelines/suicide.pdf $\quad 16.06 .19$

American Psychiatric Association. (2018). Mental Health Disparities: Muslim Americans, Retrieved from https://www.psychiatry.org/File\%20Library/Psychiatrists/Cultural-Competency/MentalHealth-Disparities/Mental-Health-Facts-for-Muslim-Americans.pdf 16.06.19

Argyle, M. \& Beit-Hallahmi, B. (1975). The Social Psychology of Religion, Routledge \& Kegan Paul, London (rev. ed. Argyle 1958).

Aronson, E., Wilson T. D. \& Akert, R. M. (2005). Social Psychology, Fifth Edition, Pearson Education Inc. New Jersey.

Ashbrook, J. B. (1997). Mind As Humanizing The Brain: Toward A Neurotheology Of Meaning. Zygon, vol. 32, no. 3. 
Ashbrook, J. B. \& Albright, C. R. (1999). Religion and Science Conversation: A Case Illustration. Zygon, vol. 34, no. 3.

Attala, J. \& Orwig, J. \& Salter, L. (2018). A Neuroscientist Explains Why Reality May Just Be A Hallucination. Business Insider, Retrieved from https://www.businessinsider.com/neuroscientistexplains-why-reality-hallucination-meaning-2018-3 $\quad 16.06 .19$

Batson, D. C. \& Schoenrade, P. \& Ventis, W. L. (1993). Religion and the Individual, Oxford University Press, New York.

Belzen, J. A. (2010). Towards Cultural Psychology of Religion, Principles, Approaches, Applications, Springer Science+Business Media B.V.

Berger, P. L. (1990). The Sacred Canopy: Elements of a Sociological Theory of Religion, Anchor Books, Random House Inc. New York.

Berger, P. L. (2013). Identity as a Problem in the Sociology of Knowledge, in Pfadenhauer, M., The New Sociology of Knowledge, The Life and Work of Peter L. Berger, Transaction Publishers, New Brunswick, New Jersey

Bhalla D. (2018). Practice of Religion as a Therapeutic Tool For Obtaining Neuropsychiatric Benefits, Mathews Journal of Neurology, 3(1): 011.

Bird, Y. M. (2005). Neurodecolonization, Using Mindfulness Practices to Delete The Neural Networks of Colonialism. in Waziyatawin, A. W. \& Bird, M. Y. (Eds.), For Indegenous Minds Only: A Decolonization Handbook, School of American Research.

Borchert, T. (2017). History and Diversity of Religion. in Tibayrenc, M. \& Francisco J. Ayala (Eds.), On Human Nature, Biology, Psychology, Ethics, Politics, and Religion, Academic Press, Elsevier Inc.

Bruner, J. (1995). Meaning and Self in Cultural Perspective. in Bakhurst, D. \& Christine Synowich (Eds.), The Social Self, Sage Publications, London.

Bush, D. M. \& Simmons, R. G. (1981). Socialization Process Over the Life Course. in Rosenberg, M. \& Ralph H. Turner (Eds.), Social Psychology Sociological Perspectives, Basic Books Inc. New York.

Cammack, M. (1995). In Search of the Post-Positivist Jury. Indiana Law Journal: Vol. 70: Iss. 2, Article 2, Retrieved from http://repository.law.indiana.edu/ilj/vol70/iss $2 / 2$

Cathomen, T. \& Schüle, S. \& Schüssler-Lenz, M. \& Abou-El-Enein, M. (2019). The Human Genome Editing Race: Loosening Regulatory Standards for Commercial Advantage?. Trends in Biotechnology, Vol. 37, Issue 2.

Chiao, J.Y., (2010). At the Frontier of Cultural Neuroscience: Introduction to the Special Issue. Social, Cognition and Affective Neuroscience, 5, (pp.109-110).

Clark, K. J., \& Barrett, J. L. (2011). Reidian Religious Epistemology and the Cognitive Science of Religion. Journal of the American Academy of Religion, 79, (pp. 639-675). doi:10.1093/jaarel/ $1 \mathrm{fr} 008$

Craig, W. L. (1979). The Kalām Cosmological Argument, Macmillan, London, UK

Crick, F. (1994). Astonishing Hypothesis: The Scientific Search for the Soul, Touchstone, New York.

Cunningham, P. F. (2011). Are Religious Experiences Really Localized Within the Brain? The Promise, Challenges, andProspects of Neurotheology. The Journal of Mind and Behavior, Vol. 32, No. 3, Institute of Mind and Behavior, Inc. Retrieved from https://www.jstor.org/ stable/43854461 
Dawkins, R. (2006). The God Delusion, Bantam Books, New York.

De Cruz, H. \& De Smedt, J. (2011). The Cognitive Appeal of The Cosmological Argument. Method \& Theory in the Study of Religion, 23, pp. 103-122.

Dennett, D. C. (2006). Breaking the spell: Religion as a natural phenomenon, New York, NY: Penguin.

DeSeno, D. (2019). What Science Can Learn From Religion. The New York Times, Retrieved from https://www.nytimes.com/2019/02/01/opinion/sunday/science-religion.html 16.06.19

Devine, P. G., Hamilton, D. L. \& Ostrom, T. M. (1994). Social Cognition and Classic Issues in Social Psychology. In Devine, P. G., Hamilton, D. L. \& Ostrom, T. M (Eds.), Social Cognition: Impact on Social Psychology, Academic Press Inc. U.S.A.

Dixon, S. \& Wilcox, G. (2016). The Counseling Implications of Neurotheology: A Critical Review. Journal Of Spirituality In Mental Health, Vol. 18, No. 2, Retrieved from http://dx.doi.org/10.10 80/19349637.2015.1064804

Einstein, A. (1941). In: Science, Philosophy and Religion, a Symposium. The Conference on Science, Philosophy and Religion in Their Relation to the Democratic Way of Life, New York.

Elk, M. V. \& Aleman, A. (2016). Brain Mechanisms In Religion And Spirituality: An Integrative Predictive Processing Framework. Neuroscience and Biobehavioral Reviews, 73, Elsevier, Retrieved from http://dx.doi.org/10.1016/j.neubiorev.2016.12.031

Fadilpašić, S. \& Maleč, D. \& Džubur-Kulenović, A. (2017). Relationship of Religiousness And Religious Coping With Quality of Life Among War Trauma Survivors. Psychiatria Danubina, 2017; Vol. 29, No. 3, pp 291-301 Retrieved from https://doi.org/10.24869/psyd.2017.291

Farr, R. M. (1996). Modern Social Psychology: a Characteristically American Phenomenon. The roots of Modern Social Psychology 1872-1954, Blackwell Publishers Ltd.

Festinger, L. \& H. W. Riecken \& Schachter, S. (1958). When Prophecy Fails. in Maccoby, E. E \& Newcomb, T. M. \& Eugene L. Hartley (Eds.), Readings in Social Psychology, Holt, Reinehart and Winston Inc., U.S.A.

Fleming, F. (2016). The Truth About Science \& Religion From The Big Bang To Neuroscience, Wipf and Stock Publishers, OR, USA

Fontana, D. (2003). Psychology, Religion, and Spirituality, British Psychological Society and Blackwell Publishing Ltd.

Franzoi, S. L. (2003). Social Psychology, Third Edition, The McGraw-Hill New York.

Gallup Poll. (2011). Evolution, Creationism, Intelligent Design. Retrieved from http://www.gallup. com 15/12/2015.

Geertz, C. (1973). The Interpretation of Cultures. Basic Books, New York.

Gergen, K. J. (1997). Social Psychology as Social Construction: The Emerging Vision. in McGarty, C. \& Haslam, A. S. (Eds.), The Message of Social Psychology, Perspectives on Mind in Society, Blackwell Publishers Ltd.

Gergen, K. J. (2010). The Acculturated Brain. Theory \& Psychology, Vol. 20 (6): 1-20 DOI: $10.1177 / 0959354310370906$

Gergen, K.J. (1998). Construction and Realism: How Are We to Go On. in Parker, I. (Ed.), Social Constructivism, Discourse and Realism, Sage Publications.

Gold, M. \& Douvan, E. (1997). A New Outline of Social Psychology. American Psychological Association, Washington D.C. 
Gripentrog, S. (2018). Mapping The Boundaries Between Science and Religion. In Lüddeckens, D. \& Monika Schrimpf(Eds.), Medicine-Religion-Spirituality, Global Perspectives on Traditional, Complementary, and alternative Healing, Verlag, Bielefeld.

Hall, G. S. (1917). Jesus, the Christ, in the light of Psychology, Doubleday, New York.

Helminiak, D. A. (2010). Theistic Psychology And Psychotherapy: A Theological And Scientific Critique. Zygon, vol. 45, no. 1.

Hirst, W. \& Davd Manier. D. (2008). Opening Vistas for Cognitive Psychology. In Martin, L. \& Nelson, K. and Ethel Tobach, Sociocultural Psychology, Theory and Practice of Doing and Knowing, Cambridge University Press.

Hofstede, G. (1980). Culture's Consequences: International Differences in Work Related Values, Beverly Hills, CA:Sage. (also reprint in 2001)

Hogg, M. A. \& Vaughan, G. M. (2005). Social Psychology, Pearson Education Limited, England.

Hogg, M. A. (2003). Introducing Social Psychology. Social Psychology, Vol.1, Sage Publications, London.

Hood Jr., R. W. (2012). The History and Current State of Research on Psychology of Religion, in Miller, L. J. The Oxford Handbook of Psychology and Spirituality, Oxford University Press, New York.

Hood, Jr. R. W. \& Hill, P. C. \& Spilka, B. (2009). The Psychology of Religion, an Empirical Approach, Fourth Edition, The Guilford Press, U.S.A.

Jackson, J. M. (1988). Social Psychology, Past and Present, An Integrative Orientation, Lawrence Erlbaum Associates Inc. New Jersey.

James, W. (1902). The Varieties of Religious Experience: A Study in Human Nature, Cambridge MA: Harvard University Press (reprint 1985).

James, W. (1902). The Varieties of Religious Experience: A Study in Human Nature, Longmans, Green, And Co. Cambridge University Press (digitally printed version 2012).

Jeeves, M. \& Brown, W. S. (2009). Neuroscience, Psychology, and Religion: Illusions, Delusions, and Realities about Human Nature, Templeton Foundation Press, USA

Jeeves, M. (2008). Psychologising and Neurologising about Religion: Facts, Fallacies and the Future Transcript, Gresham College, Retrieved from https://www.gresham.ac.uk/lecture/ transcript/download/psychologising-and-neurologising-about-religion-facts-fallacies-and-thefuture/ 16.06 .19

Jong, J. (2012). Explaining Religion (Away?) Theism and the Cognitive Science of Religion. Sophia, 52, pp.521-533, Springer Science + Business Media B.V., DOI 10.1007/s11841-0120338-9

Jung, C (1963). Memories, Dreams, Reflections, Collins \& Routledge \& Kegan Paul, London.

Kim-Prieto, C., \& Miller, L. (2018). Intersection of Religion and Subjective Well-Being. in E. Diener, S. Oishi, \& L. Tay (Eds.), Handbook of Well-Being, Salt Lake City, UT: DEF Publishers. DOI:nobascholar.com

Koenig, H. G. \& Larson, D. B. (2001). Religion And Mental Health: Evidence For an Association. International Review of Psychiatry, 13, pp. 67-78 Carfax Publishing, DOI: 10.1080/09540260120037290

Koenig, H. G. (2012). Religion, Spirituality and Health: The Research and Clinical Implications., ISRN Psychiatry, http://dx.doi.org/10.5402/2012/278730 07.06.19 
Koenig, H. G. (1994). Aging and God: Spiritual pathways to mental health in midlife and later years, Haworth Pastoral Press, New York

Kuhn, T. S. (1962). The Structure of Scientific Revolutions, University of Chicago Press.

Kyriacou, D. (2018). Are We Wired For Spirituality? An Investigation Into The Claims Of Neurotheology. HTS Teologiese Studies/ Theological Studies 74(3), 4973. https:/doi. org/10.4102/hts.v74i3.4973

Lager, J. M. (2006) Relationship Among Religious Coping, Psychosocial Factors, And Quality Of Life In Individuals With Type 2 Diabetes, PhD Dissertation, Texas A\&M University.

Lahti, D. (2019) in Horgan, G., "Be Careful with Occam's Razor, You Might Cut Yourself", Scientific American, Avalable at: https://blogs.scientificamerican.com/cross-check/be-carefulwith-occams-razor-you-might-cut-yourself/?redirect=1 $\quad 16.06 .19$

Larson, D. B. (1996) "Have Faith: Religion Can Heal Mental Illness", In B. Slife (Ed.), Taking Sides: Clashing Views on Controversial Psychological Issues (pp. 388-392). Guilford, CT: Dushkin Publishing Group

Lehmann-Muriithi, K. (2017). "Report on Cultural Psychology: A new science of the human nature, Yokohama 2016", Journal of Mediterranean Knowledge-JMK, 2(1), 123-128. DOI: 10.26409/2017JMK2.1.09

Levin, J. (2016) "Prevalence and religious predictors of healing prayer use in the usa: Findings from the baylor religion survey", Journal of Religion and Health, 55(4), 1136-1158. https://doi. org/10.1007/s10943-016-0240-9.

Makwana, A. \& Grön, G. \& Fehr, E. \& Hare, T. A. (2015). A Neural Mechanism of Strategic Social Choice Under Sanction-Induced Norm Compliance. eNeuro, 2(3), DOI:http://dx.doi. org/10.1523/ENEURO.0066-14.2015

Mantovani, P. (2018). "Minimal Intellectualism and Gods as Intuitive Regress-Blockers. In H. van Eyghen et al. (eds.), New Developments in the Cognitive Science of Religion, New Approaches to the Scientific Study of Religion, https://doi.org/10.1007/978-3-319-90239-5_8

Martin, E. (2000). Mind-body problems. American Ethnologist, 27, pp. 569-590.

Maslow, A. H. (1962). Toward a Psychology of Being, Van Nostrand, NewYork.

Maslow, A. H. (1970). Religions, Values, and Peak-Experiences, Penguin, New York.

McDermott, R. (2017). Culture, Brain and Behavior: The Implications of Neural Plasticity and Development on Social Context and Political Structures. in Tibayrenc, M. \& Francisco J. Ayala (Eds.), On Human Nature, Biology, Psychology, Ethics, Politics, and Religion, Academic Press, Elsevier Inc.

McIlhenny, R. (2010). God is in Your Head: Neurotheology and Religious Belief., in Murphy, G. (Ed.), American Theological Inquiry, Biannual Journal of Theology, Culture \& History, Vol 3, Issue 2, Minneapolis.

McPhetres, J. \& Nguyen, T. T. (2018). Using Findings From The Cognitive Science Of Religion To Understand Current Conflicts Between Religious And Scientific Ideologies. Religion, Brain \& Behavior, Vol. 8, No. 4, Routledge, https://doi.org/10.1080/2153599X.2017.1326399

Mcrae, M. (2018). This Quantum Theory Predicts That The Future Might Be Influencing The Past. ScienceAlert Pty Ltd., Retrieved from https://www.sciencealert.com/quantum-physics-theorypredicts-future-might-influence-the-past-retrocausality 16.06 .19

Mead, G. H. (1934). Mind, Self \& Society from the Standpoint of a Social Behaviorist, in Morris, C. W. (Ed.), University of Chicago Press, Chicago, U.S.A. 
Miller, L. J. (2012). Introduction. In Miller, L. J. The Oxford Handbook of Psychology and Spirituality, Oxford University Press, New York.

Mishra, S. K. \& Togneri, E. \& Tripathi, B. \& Trikamji, B. (2015). Spirituality and Religiosity and Its Role in Health and Diseases. Journal of Religion and Health, 56, pp.1282-1301, DOI $10.1007 / \mathrm{s} 10943-015-0100-\mathrm{z}$

MIT Technology Review (2019). A Quantum Experiment Suggests There's No Such Thing as Objective Reality. Emerging Technology From the ArXiv, Retrieved from https:/www. technologyreview.com/s/613092/a-quantum-experiment-suggests-theres-no-such-thing-asobjective-reality/ 16.06 .2019

Morgan, J. H. (2011). Psychology of Religion A Commentary on the Classical Texts, Graduate Theological Foundation, Retrieved from https://www.google.com.tr/url?q=https://www. gtfeducation.org/images/dynamic/file/books/PSYCHOLOGY-OF-RELIGION.pdf\&sa=U\&v ed=2ahUKEwjF45mKvMviAhUD4KYKHUL2BMkQFjACegQIBRAB\&usg=AOvVaw08MbzVv-EoGOIo1CazVQf $\quad 16.06 .19$

Myers, D. G. (2000). The Funds, Friends, And Faith of Happy People. American Psychologist, 55(1), pp. 56-67, doi:10.1037/0003-066X.55.1.56

Newberg, A. (2016). How God Changes Your Brain: An Introduction to Jewish Neurotheology. CCAR Journal: The Reform Jewish Quarterly, Winter 2016, Central Conference of American Rabbis, New York.

Newberg, A. (2010). Principles of Neurotheology, Ashgate Publishing Limited, England.

Nissen, R. D. \& Gildberg, F.A. \& Hvidt, N. C. (2018). Psychiatry, a Secular Discipline in a Postsecular World? A Review. Religions, 9, 32; doi:10.3390/re19010032

Norman, W. D. \& Jeeves, M.A. (2010). Neurotheology: Avoiding a Reinvented Phrenology. Perspectives on Science and Christian Faith, Vol. 62, No. 4, American Scientific Affiliation.

Oman, D. (2018). Model of Individual Health Effects from Religion/Spirituality: Supporting Evidence. in Oman, D. (Ed.), Why Religion and Spirituality Matter for Public Health Evidence, Implications, and Resources, Religion, Spirituality and Health: A Social Scientific Approach, Springer International Publishing.

Pargament, K. I. (1997). The Psychology Of Religion And Coping: Theory, Research, And Practice, New York: Guilford Press, 1997.

Pargement, K. I. \& Hill, P. C. (2003). Advances in the Conceptualization and Measurement of Religion and Spirituality, Implications for Physical and Mental Health Research. American Psychologist, Vol 58, No. 1.

Pepitone, A. (1997). Nonmaterial Beliefs: Theory and Research in Cultural Social Psychology. In McGarty, C. \& Haslam, A. S. (Eds.), The Message of Social Psychology, Perspectives on Mind in Society, Blackwell Publishers Ltd.

PEW Research Center (2019) Religion's Relationship to Happiness, Civic Engagement and Health Around the World. Religion and Public Life, Retrieved from https://www.pewforum. org/2019/01/31/religions-relationship-to-happiness-civic-engagement-and-health-around-theworld/ 16.06 .19

Pyysiäinen, I. (2014). Cognitive Science of Religion. in Watts, F. \& Leon Turner (Eds.), Evolution, Religion, and Cognitive Science: Critical and Constructive Essays, Oxford University Press, UK. 
Quran, Kuran-1 Kerim, Diyanet İşleri Başkanlı̆̆l, Retrieved from http://kuran.diyanet.gov.tr/ mushaf/kuran-meal-1/fatiha-suresi-1/ayet-1/diyanet-isleri-baskanlıg1-meali-1 16.06 .19

Reber, J. S. (2006). Secular Psychology: What's The Problem? Journal of Psychology and Theology, Vol. 34, No. 3, pp. 193-204, Rosemead School of Psychology, Biola University.

Rosmarin, D. H., Pargament, K. I., \& Mahoney, A. (2009). The role of religiousness in anxiety, depression, and happiness in a Jewish community sample: A preliminary investigation. Mental Health, Religion \& Culture, 12, pp. 97-113, doi:10.1080/13674670802321933

Samuels, R. (2017). Psychoanalyzing the Politics of the New Brain Sciences, Palgrave Macmillan, Springer International Publishing AG, Cham, Switzerland.

Saniotis, A. (2015). Understanding Mind/Body Medicine from Muslim Religious Practices of Salat and Dhikr. Journal of Religion and Health, 57 (3), DOI 10.1007/s10943-014-9992-2

ScienceDaily (2018). Scientists Identify a New Kind of Human Brain Cell. Allen Institute, Retrieved from https://www.sciencedaily.com/releases/2018/08/180827180809.htm 16.06.19

Semin, G. (1997). The Relevance of Language for Social Psychology. in McGarty, C. \& Haslam, A. S. (Eds.), The Message of Social Psychology, Perspectives on Mind in Society, Blackwell Publishers Ltd.

Seybold, K. (2007). Explorations in Neuroscience, Psychology and Religion, Ashgate Publishing Limited, England.

Sherman, S. J., Judd, C., \& Park, B. (1989). Social Cognition. in M.R. Rosenzweig \& L. W. Porter (Eds.), Annual Review of Psychology, Vol. 40, pp.281-286, Palo Alto, CA: Annual Reviews.

Smith, P. B. \& Bond, M. H. (1998). Social Psychology Across Cultures, Prentice Hall Europe, Hertfordshire.

Society for Christian Psychology (2019). Mission Statement. in Palmer. K., Christian Psychology: An Introduction \& Biblical Analysis, Association of Certified Biblical Counselors, Retrieved from https://biblicalcounseling.com/resources/acbc-essays/christian-psychology-introductionbiblical-analysis/\#_ftn37 16.06.19

Spinks, G. S. (1963). Psychology and Religion, Methuen, London.

Still, A. (1998). Historical Origins of Social Psychology. in Sapsford, R. \& Still, A. \& Miell, D. \& Stevens, R. \& Margaret Wetherell (Eds.), Theory and Social Psychology, Sage Publications in association with Open University.

Tolstoy, L. N. (1893 / 1987) Religion and Morality. in A Confession and Other Religious Writings (J. Kentish, trans.), Penguin, New York.

Triandis, H. C. (1994). Analyzing Subjective Culture. Culture and Social Behavior, McGraw Hill Inc. U.S.A.

Turner, L. (2014). Neither Friends nor Enemies: The Complex Relationship Between Cognitive and Humanistic Accounts of Religious Belief. in Watts, F. \& Leon Turner (Eds.), Evolution, Religion, and Cognitive Science: Critical and Constructive Essays, Oxford University Press, UK.

Van Bavel, J. \& Haslam, A. S. \& Reicher, S. (2019). Rethinking the Infamous Stanford Prison Experiment. Scientific American, Retrieved from https://blogs.scientificamerican.com/ observations/rethinking-the-infamous-stanford-prison-experiment/?redirect=1 $\quad 16.06 .19$

Varvatsoulias, G. (2013). Cognitive Behavioural Therapy: A Transformative Approach to Negative Appraisals of Religious Origin. Psychological Thought, Vol. 6(1), pp. 62-74, doi:10.5964/psyct. v6i1.61. 
Verschuuren, G. M. (2017). Religion Viewed from Different Sciences. in Tibayrenc, M. \& Francisco J. Ayala (Eds.), On Human Nature, Biology, Psychology, Ethics, Politics, and Religion, Academic Press, Elsevier Inc.

Walkerdine, V. \& Blackman, L. (2008). Psychology and Cultural Analysis, in Bennet, T. \& John Frow (Eds.), The Sage Handbook of Cultural Analysis, Sage Publications, London.

Weker, M. (2016). Searching for Neurobiological Foundations of Faith and Religion. Studia Humana, Vol. 5:4, DOI: 10.1515/sh-2016-0024

White, A. D. (1896). A History of Te Warfare of Science With Theology in Christendom, D. Appleton and Company, New York, Retrieved from https://archive.org/details/ahistorywarfare00goog/ page/n3 16.06.19

Whitehouse, H. (2008). Cognitive Evolution and Religion; Cognition and Religious Evolution. Researchgate, Retrieved from https://www.researchgate.net/publication/255849004 16.06.19

Williams Jr., R. M. (1958). Religion, Value Orientations, and Intergroup Conflict. in Maccoby, E. E \& Newcomb, T. M. \& Eugene L. Hartley (Eds.), Readings in Social Psychology, Holt, Reinehart and Winston Inc., U.S.A.

Wissenbacher, A. C. (2015). Ten Principles for Interpreting Neuroscientific Pronouncements

Regarding Human Nature. Dialog: A Journal of Theology, Vol. 54, No 1. Wiley Periodicals and Dialog, Inc.

Wundt, W. (1912). An Introduction to Psychology, London: George Allen \& Unwin, Ltd. Ruskin House, 40 Museum St. W.C. 1. (Reprinted in 1924) Available at: https://archieve.org/details/ principlesofphys00wundiala/page/n6 11.12.2019

Xuzhou, L. \& Weissman, M. \& Talati, A. \& Svob, C. \& Wickramaratne, P. \& Posner, J. \& Dongrong Xu (2019). A Diffusion Tensor Imaging Study of Brain Microstructural Changes Related to Religion and Spirituality in Families at High Risk for Depression. Brain and Behavior published by Wiley Periodicals, Inc., https://doi.org/10.1002/brb3.1209 